See discussions, stats, and author profiles for this publication at: https://www.researchgate.net/publication/339644740

\title{
The Effects of Amalgamations on Voter Turnout: Evidence from Sub-Municipal Governments in Portugal
}

Article in Cities · March 2020

DOI: $10.1016 /$ j.cities.2020.102685

CITATIONS

2

2 authors:

Miguel Angelo Vilela Rodrigues

University of Minho

25 PUBLICATIONS 156 CITATIONS

SEE PROFILE

Some of the authors of this publication are also working on these related projects:

Social Media for Digital Democracy View project

Intermunicipal Cooperation in Europe View project
READS

253

António Tavares

University of Minho

69 PUBLICATIONS 1,029 CITATIONS

SEE PROFILE 


\title{
Forthcoming: Cities: The International Journal of Urban Policy and Planning
}

\section{The Effects of Amalgamations on Voter Turnout: Evidence from Sub-Municipal Governments in Portugal}

Miguel Rodrigues* , António Tavares *†

* Research Center in Political Science, School of Economics and Management, University of Minho, Portugal

† United Nations University, Operating Unit on Policy-Driven Electronic Governance, Portugal

\begin{abstract}
The 2013 territorial reform of sub-municipal units (SMUs) of government in Portugal presents an interesting opportunity to understand the effect of amalgamations on democratic outcomes. Like other reforms of its kind, the Portuguese amalgamation reform was triggered by economic motivations, aimed at improving local services but seeking mostly to reduce the level of public expenditures. Much less relevance was given to the political impacts of territorial consolidation. The aim of this research is to assess the impacts of the Portuguese territorial reform on political participation measured as voter turnout in SMU elections. We use data from five election cycles (2001-2017) to compare turnout levels in amalgamated jurisdictions vis-à-vis the ones that did not amalgamate as a result of the process of territorial reform. The results of this quasi-experimental design indicate that turnout levels after the reform have decreased in the 2013 election and recovered in the 2017 election, but the negative effects were much more pronounced in amalgamated SMUs than in nonamalgamated SMUs.
\end{abstract}




\section{Introduction}

The consequences of municipal amalgamations have been investigated in many countries, including Denmark (Blom-Hansen, 2010; Blom-Hansen et al. 2014; Blom-Hansen et al, 2016), Finland (Saarimaa and Tukiainen, 2015), Germany (Blesse and Baskaran, 2016; Roesel, 2017), Greece (Chorianopoulos, 2011), Sweden (Hansen, 2014; Hansen et al. 2014), Switzerland (Steiner and Kaiser, 2017), Belgium (De Ceuninck et al., 2010), The Netherlands (Allers and Geertsema, 2016; Bikker and van der Linde, 2016), and New Zealand (Imran and Pearce, 2015; McArthur, 2017). This group of empirical studies focuses primarily on the economic, financial and competitiveness effects of amalgamations.

In contrast, the number of research articles focusing on the political consequences of amalgamations is more limited, particularly in terms of the effects of mergers 1 on voter turnout, but the number of studies has grown in recent years.2. Empirical work has documented negative effects of amalgamation for sub-national turnout levels in Austria (Styria) (Heinisch et al., 2018), Finland (Lapointe et al., 2015), Germany (Roesel, 2017), Israel (Zeedan, 2017), Japan (Horiuchi et al., 2015) and Switzerland (Canton of Ticino) (Koch and Rochat, 2017).

Our study extends this growing body of research in a couple of ways. First, it focuses on the political effects of the amalgamation of Portuguese sub-municipal governments, enacted in 2013 as part of the financial bailout agreement signed by the Portuguese government with the European Commission, the International Monetary Fund and the European Central Bank.

1 This article uses the terms 'amalgamation', 'merger' and 'territorial consolidation' interchangeably. 2 For an in-depth review of the effects of municipal amalgamations, see Tavares (2018). 
The amalgamation process was implemented in a compulsory manner, reducing the number of sub-municipal units (SMUs) by about 1,200 (about 30 percent) and increasing their size in an attempt to boost efficiency, seize economies of scale, and reduce the costs of service delivery. Local citizens had little influence over the process of deciding which criteria should be used and which jurisdictions should be merged. Intuitively, one would expect negative political impacts to occur, threatening local identities, political representation, and democratic performance. In order to assess the merits of this intuition, this article adopts a quasi-experimental design with pre- and post-treatment observations for both an experiment and a control group to investigate the effects of the territorial amalgamation of SMUs on voter turnout levels.

Second, we investigate the effects of amalgamations at the sub-municipal level. The relevance of 'the neighborhood' as a unit of analysis is stressed by Lowndes and Sullivan (2008). The authors highlight the civic, social, political, and economic role played by neighborhoods in contemporary governance. Although it has been argued that SMUs of government in Portugal are similar in size to some of their municipal counterparts in many European countries (Tavares and Teles, 2018), the uniqueness of this second tier of local government in Portugal places the amalgamation reform in a different context from the 'typical' municipal amalgamation reforms in other European countries. In the Portuguese case, the national government provided the legal framework for the reform, but municipal assemblies could decide if they chose to, which SMUs to amalgamate, as long as this process complied with the criteria defined in the national legal framework (Tavares and Teles, 2018). Thus, despite the similarities in size between Portuguese SMUs and municipalities elsewhere in Europe (e.g. France) the institutional context of the Reform is significantly different, since 
the fate of Portuguese SMUs depended upon the decision of both the national and municipal governments.

The article is structured as follows. After this introduction, the second section explores the theoretical foundations of the relationship between jurisdiction size, amalgamations and voter turnout. Next, we review the empirical literature on the political consequences of amalgamations. The fourth section describes the context of the research focusing on the amalgamation reform of sub-municipal governments in Portugal and introduces the hypotheses to be tested. The fifth section presents the data and methods employed in the empirical analysis conducted in section six. The article closes with the discussion of the findings, conclusions, and future avenues of research.

\section{Municipal Amalgamations and Voter Turnout: Theoretical Foundations}

The theoretical debate concerning the effects of municipal amalgamations on voter turnout is largely premised on the argument that amalgamations create local government units which are 'too large' to allow their citizens to effectively express their political preferences through the institutions of representative democracy (Verba, Nie and Kim, 1978; Denters et al., 2014). This discussion about the relationship between the size of the polity and democracy dates back to Ancient Greece. Aristotle argued that a polis should be large enough to be selfsufficient, but not so large that its citizens are unable to know each other and know what kind of people they are (Dagger 1981).

In the 1967 article 'The City in the Future of Democracy', Robert Dahl advanced a solution to the size dilemma based in "smaller units within which citizens can from time to time formulate and express their desires, consult with officials, and in some cases participate even 
more fully in decisions." Smaller units of local government can provide unlimited opportunities for participation and are able to foster a sense of unity, integrity, and belonging.

The 1973 book by Robert Dahl and Edward Tufte, Size and Democracy triggered a stream of research to test the arguments linking size to political participation. On one hand, Dahl and Tufte readily claim that the motivation of citizens to participate in community affairs is maximized in small communities, since a small polity offers a sense of solidarity and greater effectiveness in participation. On the other hand, they recognize that larger communities are more likely to provide the motivation for citizens to participate in political life, particularly matching different groups with different political views. Various empirical works over the past few decades have supported the first part of Dahl and Tufte's argument, finding a negative relationship between the size of subnational units and electoral participation at the local level (Verba, Nie, and Kim 1978; Oliver 2001, 2012; Frandsen, 2002; Ladner 2002; Larsen 2002; Tavares and Carr 2013; Trounstine 2013). Recent surveys of the literature on the determinants of electoral participation point in a similar direction (Geys, 2006; Cancela and Geys, 2016; McDonnell, 2019).

Here, we argue that it is possible to extend the theoretical reasoning of the size and participation literature to the empirical research on the political effects of amalgamations. Three streams of literature point to a negative impact of amalgamations on electoral participation, whereas a small number of theoretical arguments suggests a positive impact. The remainder of this section explores the theoretical foundations of the negative relationship based on the three streams of the literature: 1) the rational voter model; 2) the social trust and cohesion model; and 3) the political protest and local identity literature. The section ends 
with the theoretical rationale for a positive relationship between amalgamations and voter turnout.

\section{The Rational Voter Model}

Rational voters aim to influence the outcome of the election by weighting the costs and benefits of voting (Downs 1957). The benefits increase significantly in small-scale elections and this increases the probability of affecting the outcome of the election (Riker and Ordeshook 1968). Geys argues that "the greater the size of the community, the smaller the probability becomes that one single voter will make a difference. This decreases the expected utility from voting and makes it more likely that one abstains." (2006: 642). Thus, it can be expected that voter turnout will be higher when elections are too close to call and a few votes can make a difference. In this context, voters have more opportunity to influence the outcome of an election and citizens will have more contact with their elected officials (Hajnal and Lewis, 2003; Wood 2002).

Amalgamation reforms increase the average size of amalgamated jurisdictions, decreasing the probability of casting the decisive vote. The worsening of the ratio of elected representatives to the number of voters caused by municipal amalgamations has also been negatively associated with public participation in local affairs (CoE, 1995; Chorianopoulos, 2011). The meta-analysis of 83 studies conducted by Benny Geys (2006) finds empirical support for the rational voter model, stating that the inclusion of population size measures in the analyses of the determinants of voter turnout is suggested by the probability of casting the decisive vote in the election. 


\section{Social Trust and Political Embeddedness Model}

A second stream of literature suggests that amalgamations may affect the levels of social trust and citizen engagement in the political life of the community. Early sociologists argued that larger communities experience a significant shift in social relationships that prevents each individual in the community from knowing all others personally (Simmel, 1903; Wirth, 1938). The increased number of citizens per jurisdiction is likely to affect collective action as well, resulting in lower engagement in political activities, including turnout. The increased heterogeneity of urban life described in these early works is similar to the effects of municipal mergers, which have been associated with declining community attachment (Kushner and Siegel, 2003; Swianiewicz, 2002) and lower levels of social trust and cohesion, (Denters et al. 2014; Oliver, 2001). Amalgamations may also increase dissatisfaction with government among citizen-voters and lead to decreased participation in local elections (Hansen, 2015).

While these changes are based on citizen perceptions and impressions, other effects of municipal amalgamations are factual. The sudden shift in size of merged jurisdictions effectively reduces the number of representatives per voter (Horiuchi et al., 2015) and increases the political distance between voters and elected officials (Dahl and Tufte, 1973; Denters et al., 2014; Newton, 1982; Roesel, 2017). By increasing the size of municipalities, amalgamation reforms may generate a biased representation since elected officials will be

serving only a small segment of the residents (Hajnal and Lewis, 2003). All these negative effects - be they perceived or factual - affect social cohesion and citizen engagement in politics and are likely associated with lower levels of voter turnout. 


\section{Political Protest and Local Identity}

Stable municipal borders help to create a strong sense of local identity (Stoker, 2011), which may feel under attack when facing an externally-imposed reform. Besides public demonstrations against the reform, one of the most obvious ways to express disagreement under duress is to abstain from voting (Hanna, 2009). While electoral boycotts are rare events, particularly in democratic states, it is certainly possible that some citizens choose to stay home as a form of protest against a territorial reform.

Amalgamation reforms are politically controversial endeavors and have been described by local actors as "an attack on our self-respect" (Zeedan, 2017: 716), generating "a much larger bureaucracy" (Fathimath, 2017: 228) or increasing the distance between citizens and their representatives (Chorianopoulos, 2011; Denters et al., 2014). In countries with a long history of local government, municipal territorial stability and absence of prior experiences of amalgamations, local autonomy may often feel threatened by territorial reforms initiated from the top (Teles, 2016).

In the particular case of SMUs in Portugal, the long-standing tradition suggests the possibility of extending this reasoning from the municipal to the sub-municipal level. After the Liberal Revolution of 1820, centuries-old Catholic parishes were converted into civil parishes as a result of a laicization process and established by law in 1836. By 1960, the number of civil parishes (SMUs) was 3,702 and their number reached a high of 4,260 in 2010 (PORDATA, 2019). The combination of a strong neighborhood identity and the absence of exogenous shocks resulted in the lock in of SMUs as institutional arrangements and their persistence for

more than a century (Boettke, Coyne, and Leeson, 2008; Pierson, 2000a, 2000b). These 
conditions suggest that the expected negative effects of amalgamations on turnout are not exclusive of the municipal level and may, in fact, carry over to the sub-municipal one.

\section{Size and Mobilization}

The theoretical arguments supporting a positive association between amalgamations and voter turnout are scarce and focus primarily on the idea that, in larger cities, community interests, political parties, and the media tend to be far better organized than in small jurisdictions and this may lead to an increased attention and mobilization of voters (Newton, 1982). The ability of larger local governments to provide more services to their citizens can also increase participation in local politics (Dahl and Tufte, 1973; Swianiewicz, 2010). In turn, this diversity and political competition in larger jurisdictions can potentially improve the responsiveness of elected officials to their constituents and contribute to mobilize voters (Denters et al., 2014). Prior amalgamation reforms have relied on the idea that larger territorial units are able to undertake a wider range of activities, thereby stimulating public participation on local politics (Hlepas, 2018). Others have argued that larger jurisdictions are more heterogeneous and diverse in terms of policy preferences and positions regarding social and political issues, which lead to increased political conflict, more intense competition in local politics and, ultimately, higher voter turnout levels (Kelleher and Lowery, 2004).

In contrast with the abundant empirical literature corroborating the negative effect of amalgamations on local democracy (Swianiewicz, 2018; Tavares, 2018), there is significantly less evidence that amalgamations have positive political effects, particularly when it comes to the levels of voter turnout. In fact, a recent review of 22 studies, reporting 37 tests of the link between municipal size and turnout, finds one single positive association, which contrasts with 26 negative effects and 10 tests reporting no statistically significant 
relationship (McDonnell, 2019). The following section reviews the literature on the effects of amalgamation reforms on democratic outcomes with a special emphasis on voter turnout.

\section{Empirical Evidence of the Political Effects of Amalgamations}

Most amalgamation reforms have been motivated by arguments related to economies of scale and cost savings and far less attention has been paid to the long-term consequences of the reforms to the quality of local democracies. Political rhetoric by central government officials overstates the positive effects of amalgamations on costs and agendas favoring centralization are actively pursued by international organizations, such as the European Commission and the International Monetary Fund. This optimism regarding the economic consequences is in stark contrast with the democratic outcomes of territorial reforms. The analysis of the empirical literature suggests that the political effects of amalgamations are generally negative, regardless of the specific type of consequences scholars have investigated (Tavares, 2018).

The number of studies investigating the effect of municipal amalgamations on voter turnout is still small, but has grown in recent years. Early work by Mabuchi (2001) using descriptive election data of postwar amalgamations in Japan finds that voter turnout is not significantly affected by amalgamations. However, the author does not employ multivariate analysis, so these results are not robust.

Recent empirical studies are more sophisticated in their treatment of the causal link between municipal amalgamations and voter turnout. Horiuchi et al. (2015) investigate the impact of Japan's municipal mergers in the early 2000 s and find a substantial reduction in turnout at the national level. Using a mixed-methods approach, van Houwelingen (2017) finds a 
decrease in electoral participation in the Netherlands as the outcome of municipal mergers. Roesel (2017) employs the synthetic control method to investigate the political effects of district amalgamations in the Germany state of Saxony. The amalgamation reduced the number of districts from 22 to 10 and resulted in the increase of average district population from 113,000 to 290,000 residents. The author finds that the reform resulted in a decrease in the number of candidates and voter turnout in district elections. Similarly, a study by Zeedan (2017) explores the consequences of a 2003 amalgamation reform of 24 municipalities in Israel. The 11 amalgamated municipalities resulting from the reform display voter turnout levels between $75 \%$ and $90 \%$ lower than before the amalgamation.

Koch and Rochat (2017) employ OLS panel fixed-effects regression to study the impacts of three 'waves' of amalgamations in the Swiss Canton of Ticino and find significant decreases in turnout, especially in the first election after the first 'wave' of amalgamations. The authors also find that differences in turnout increase with the passage of time for the first 'wave' of mergers, but the third 'wave' experienced the lowest reduction in turnout levels. This underlines the importance of studying the effects of mergers in the long run rather than simply looking at the effect in the first election after the reform. Heinisch et al. (2018) underline the negative effect of mergers on citizen engagement and information about the elections in their study of the 2015 amalgamation reform in the Austrian state of Styria. The authors argue that mergers have reduced opportunities for contacting local elected officials or influencing policy decisions, which resulted in a drop in voter turnout of about 1.29 percentage points. Lapointe et al. (2018) investigate the effects of a series of amalgamations in Finland in 2009 and find a reduction of 4 percentage points in voter turnout in the smaller amalgamated municipalities and no effect for the largest municipalities involved in mergers. The authors 
attribute the negative effects on turnout to the significant decreases in voters' perceived political efficacy.

Besides the studies addressing the effect of municipal mergers on voter turnout, another group of studies, mainly from Denmark, which concentrates on other political consequences, including negative impacts on political efficacy (Lassen and Serritzlew 2011; Gendźwill and Swianiewicz, 2016), political representation (Kjaer et al. 2010; Jakobsen and Kjaer 2016; Zeedan 2017), support for incumbents after the merger Kjaer and Klemmensen 2015), splitticket voting (Elklit and Kjaer 2009), and vote shares for populist parties (Roesel 2017). All these empirical results are consistency with the theoretical argument that mergers can have negative effects in other aspect of democracy that result in diminished electoral participation by citizens. In other words, lower (internal and external) political efficacy, decline of trust in government and/or reductions in local political interest are mediators between merger effects and voter turnout (Koch and Rochat, 2017; Lapointe et al., 2018).

Table 1 displays a summary of the empirical studies addressing the political consequences of municipal amalgamations. For the most part, these studies find negative impacts on most political dimensions, including, but not limited to, voter turnout, internal political efficacy, and local representative democracy. The next section presents the research setting and the hypotheses to be tested in the empirical analyses. These hypotheses are derived from the extant literature and adapted to the specific context of the territorial reform of SMUs of government in Portugal.

[insert Table 1] 


\section{Research Context and Hypotheses}

The Portuguese Constitution recognizes civil parishes3 (freguesias) as the smallest unit of local government (article 238). Parishes are sub-municipal units of self-government composed by an elected assembly (deliberative body) and an executive council (junta de freguesia) and each parish is an integral part of the municipality which contains it (see Tavares and Teles, 2018 for an in-depth description). Each municipality can be divided into several parishes, each resembling a form of neighborhood government similar to what one can find in Germany (Kersting and Kuhlmann, 2018), Greece (Hlepas, 2018), Poland (Swianiewicz, 2014; 2018), Scandinavia (Bäck et al., 2005; Klausen, 2018), and Spain (Navarro and Pano, 2018). Nevertheless, the historical roots, long-standing tradition, and constitutional status of Portuguese parishes renders them a privileged status in terms of democratic legitimacy and service provision units. International comparisons are particularly difficult because SMUs in other European countries do not cover the totality of the national territories, tend to be created primarily in urban areas as neighborhood governments (but, see Peteri (2008) for exceptions), derive political legitimacy from a variety of sources, and display significant institutional diversity (Bäck et al., 2005; Horak and Blokland, 2012; Schaap and Daemen, 2012; see Hlepas et al., 2018 for a comprehensive review). If anything, Portuguese SMUs are primarily 'neighborhood governments' in the sense described by Lowndes and Sullivan (2008). While they can and do fulfill civic, social, and economic roles, SMUs are, first and foremost, governments with a political function. Their existence,

3 We employ the term Sub-Municipal Unit (SMU) of local government to designate a subnational government tier below the municipality. In Portugal, this tier is known as a freguesia, which can be loosely translated as parish or civil parish. 
tradition, and stability embody citizens' feelings of place attachment and local identity. Given this political representation function and the presence of political institutions which mirror their municipal government counterparts (executive and deliberative bodies), it can be argued that the theoretical reasoning and empirical studies on the effects of amalgamations at the municipal level can be extended and replicated at the SMU level.

Portuguese parishes cover the entirety of the country's land area. They are classified by law according to three types, depending on the degree of urbanization: 1) Urban parishes population density above 500 people per square kilometer or at least one neighborhood with 5,000 inhabitants or more; 2) Semi-urban parishes - with population density above 100 people per square kilometer, or a neighborhood above 2,000 and below 5,000 inhabitants; and 3) Rural parishes - all the others.

The Memorandum of Understanding (MoU) signed in 2011 by the Portuguese Government placed the country under financial assistance of the International Monetary Fund, the European Union and the European Central Bank. The MoU required a territorial reform of Portugal's local government system, which at the time was structured in two tiers, including 308 municipalities and 4251 civil parishes (SMUs). The main argument present in the MoU was that excessive territorial fragmentation caused economic inefficiencies, excessive administrative costs, and deficient service delivery (Tavares and Rodrigues, 2015). In 2013, the Portuguese national government enacted a territorial reform to merge SMUs and decided to leave untouched the territories of the municipalities.

Sixty-one municipalities adopted voluntary mergers of their SMUs in compliance with the national framework, whereas 168 municipalities were forced to accept top-down amalgamations of SMUs imposed by the Technical Unit of Territorial Administrative 
Reform (UTRAT) established by the national government to manage the reform (Tavares and Teles, 2018). The remaining 49 municipalities in Continental Portugal were not affected by the reform. The reform was implemented in the beginning of 2013 so the local elections in October took place under the new territorial organization of SMUs.

Tables 2 and 3 present the number of SMUs per number of registered voters and per area, respectively, before and after the reform. Both tables indicate important changes in the territorial landscape of SMUs. According to Table 2, all categories of population have lower absolute numbers of SMUs, except the one above 20,000 inhabitants. The category below 150 residents is now residual (only seven SMUs), with the categories between 150 and 1,000 and between 1,000 and 5,000 remaining the most frequent. More importantly, the reform resulted in larger SMUs on average, but only about $13 \%$ of SMUs are above 5,000 residents, which clearly indicates that SMUs retain their neighborhood government character, even after a substantial change. The information on Table 3 confirms this idea, since the majority of parishes (approximately 87\%) displays an area under 50 square kilometers 4.

[Tables 2 and 3 about here]

4 In the appendix, we included a table showing SMUs in comparative perspective with municipalities in selected countries. In terms of area, Portuguese SMUs are approximately the size of Hungarian municipalities, slightly smaller than Austrian municipalities, and much larger than the highly fragmented landscape of local governments in France and the Czech Republic. After the reform, the average SMU is close to the average Austrian municipality and, on average, much larger than the French or the Czech municipalities. In Portugal, the average SMU is about one tenth of the size of the average municipality, both in terms of area and population. 
The territorial reform was unpopular to all participants in the local government system, particularly at the SMUs level. The Associação Nacional de Freguesias (ANAFRE), a national association representing all parishes, organized demonstrations against the territorial reform and the President of the Association lobbied the President of Portugal, at that time, Aníbal Cavaco Silva - not to enact the legal diploma of the reform5.

Given the voices of dissent and the unpopularity of the reform, reductions in voter turnout levels were to be expected. However, the motivations for these reductions are hard to disentangle. First, consistently with the rational voter model (Downs, 1957), the amalgamation process increased the size of amalgamated SMUs, reducing the probability that the vote cast will make a difference in the outcome of the election. Second, in line with prior work by Lassen and Serritzlew (2011) and Hansen (2013, 2015), the reform has led critics to express concerns about increased distance between citizens and elected officials in the newly merged SMUs and possible lack of responsiveness as a result (see footnote 4). Lastly, the perception that the merger was largely a top-down initiative led to popular protests and accusations of it being an attempt to destroy local identity and self-government (Teles, 2016). Hence, we expected that:

$H_{1}:$ The reduction in turnout in the 2013 election was more significant in amalgamated SMUs than in non-amalgamated ones.

5 See, for example, https://www.dn.pt/portugal/interior/freguesias-pedem-a-cavaco-para-chumbar-reforma2961832.html and https://www.correiodominho.pt/noticias/freguesias-unidas-contra-a-reforma/60017 
After the initial negative impact of the reform in the 2013 election cycle, we expect some recovery in voter turnout in the 2017 elections. The first election after an amalgamation reform tends to generate important information costs for voters, who are still adjusting to the changes in population, territory, relevant policy issues, and a potentially larger pool of candidates (Kraaykamp et al., 2001). In line with these ideas, recent work by Koch and Rochat (2017) finds significant reductions in turnout in the first election after the first 'wave' of amalgamations. The level of protest against the reform is expected to subside as the new territory of the amalgamated SMU becomes consolidated, and the amalgamated governments became institutionalized. Also, many local government officials at the SMU level expected the new national government, with a different ideological stance of the one enacting the reform, to revert the previous reform, at least partially. Nevertheless, we expect that some negative effect on turnout to remain in the amalgamated SMUs, which is also consistent with the findings of Koch and Rochat (2017):

$H_{2}:$ In the 2017 election cycle, turnout recovered more significantly in nonamalgamated SMUs than in amalgamated ones.

The next section describes the data and methods employed in the empirical analysis.

\section{Empirical Analysis}

\section{Data}

Prior empirical work has focused primarily on voter turnout differences between jurisdictions of different sizes, in a given period in time, or variation in turnout before-and-after amalgamation reforms (Denters, et.al, 2014; Hansen, 2013). In this article, we seek to introduce a more dynamic approach, in line with most recent trends in research on 
amalgamations (Koch and Rochat, 2017; Lapointe et al., 2018), by analyzing parish assembly turnout in five elections spanning a period of 16 years (2001-2017), including the implementation of a territorial reform in the 2013 election. Hence, rather than testing the correlation between size and turnout, we follow the logic of experimental methods by comparing the behavior of subjects randomly assigned to a treatment - the territorial reform - and divided between the treated group - amalgamated SMUs - and the control group non-amalgamated SMUs.

We opted to divide our analysis in three distinctive periods: (1) 2001-2009; (2) 2009-2013; (3) 2013-2017. For the first period, we gathered information on turnout in parish elections in 2001, 2005, and 2009. This is the period before the territorial reform and we do not expect to see major differences in turnout levels between non-amalgamated and (to be) amalgamated SMUs. Any differences that might exist cannot be accounted for by the territorial reform and we expect to see a common pattern in turnout levels between the two groups.

The second period focuses on the amalgamation process, i.e., the changes in turnout between the 2009 and the 2013 elections. The electoral cycle coincided with the effective implementation of the territorial reform. The 2013 elections were schedule to elect new officials in all SMUs, including the newly amalgamated ones. Regardless of the theoretical rationale, citizens had fewer incentives to vote in amalgamated SMUs. Hence, we expect to see a drop in turnout levels under these circumstances.

The last period spans the 2013 and 2017 elections. The 2017 election was the second electoral moment after the 2013 territorial reform. We aim to investigate if the effect of amalgamations, along with the rationale that guided the decision to vote in 2013 , still influences turnout or if the effect faded away with time. 


\section{Econometric model and estimation strategy}

To address the main objective of the paper, we follow a methodology able to assess the specific effect of a policy on the outcome of a group. In other words, we adopt a strategy that allows us to measure the effect of the territorial reform on the SMU turnout levels. The Differences-in-Differences (DiD) method allows us to assess changes in outcomes over time between a population affected by a reform and one that was not affected. As Blom-Hansen et.al. (2014) put it, the DiD estimates a combined effect of treatment and time by computing the changes in differences among treated and non-treated groups. Assuming that turnout in amalgamated SMU $i$ is given by $\mathrm{Y}_{\mathrm{i} 1}$ we seek to compare it with the $\mathrm{Y}_{\mathrm{i} 0}$ which represents the level of turnout in non-amalgamated SMUs. The key aspect of the design is that SMUs cannot be, simultaneously, amalgamated and non-amalgamated. Hence, DiD compares amalgamated SMUs, taking non-amalgamated as the counterfactual, using two periods in time. The first difference is computed by the variation in the treated group before-and-after

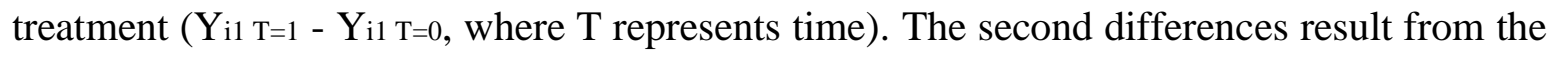
change in the control group before-and-after treatment and stands for the effect of time ( $\mathrm{Y}_{\mathrm{i} 0}$

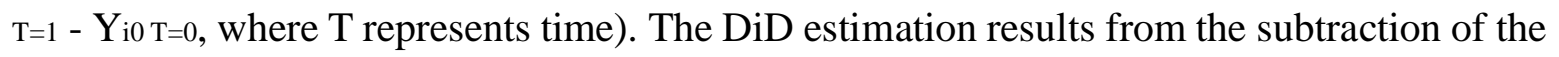

first by the second difference and reflects the effect of the treatment on the treated group ((Yi1 $\mathrm{T}=1-\mathrm{Y}_{\mathrm{i} 1 \mathrm{~T}=0)}-\left(\mathrm{Y}_{\mathrm{i} 0 \mathrm{~T}=1}-\mathrm{Y}_{\mathrm{i} 0 \mathrm{~T}=0)}\right) 6$.

6 We could use propensity score matching as an alternative estimation strategy. This method is employed to compare the effects of a policy or program on a group by building an artificial comparison group. This comparison is computed through propensity scores that match units from the treatment group with others from the untreated group, relying on observed characteristics that are not affected by the treatment (Gertler et. al, 2011). The method is useful to assess the post-treatment effect, since it compares the differences in outcomes between the enrolled units and their matched units. The estimations and results are consistent with the DiD results. Since we have available data 
By establishing the differences between the treated and untreated groups, before-and-after the territorial reform, it is possible to assess the outcome (turnout levels) by using the following expression:

$$
\begin{aligned}
& \text { Turnout }_{i, t}=\beta_{1}+\beta_{2} \text { Treated }_{i, t-1}+\beta_{3} \text { Time }_{i, t} \\
& +\beta_{4} \text { Treated }_{i, t} \times \text { Time }_{t}+\beta_{5} \text { Type }_{i, t}+\varepsilon_{i, t}
\end{aligned}
$$

The $\beta_{2}$ coefficient estimates the differences in turnout between treated and untreated groups before the reform. The $\beta_{3}$ coefficient provides information on the changes in turnout levels that cannot be accounted for by the treatment (the territorial reform). The $\beta_{4}$ coefficient provides the estimation of the main variable of interest, i.e., the average effect of the treatment on the amalgamated group. Thus, it provides the estimation of the effect on turnout induced by the territorial reform, taking as counterfactual the turnout levels recorded by parishes unaffected by the territorial reform. Additionally, we added a control variable $\left(\right.$ Type $_{i, t}$ ) which typifies the nature of the SMU. It takes the value '1' if the SMU is classified as urban and ' 0 ' otherwise. The $\beta_{5}$ coefficient provides information about the difference in turnout between urban and non-urban SMUs. Prior findings in the Portuguese context indicate that urban and more populated SMUs will display lower turnout levels (Tavares and Raudla, 2018). We build three estimations corresponding to the three periods of interest.

In Equation 1 the variable Treated $_{i, t-1}$ is computed as a dummy variable that takes value 1 to identify treated SMUs and 0 otherwise. The variable Time $_{i, t}$ is also a dummy variable used to distinguish different electoral years in the three periods of interest. The years depend

from the SMU elections, we chose a DiD estimation to display and analyze the trend in turnout between enrolled and not enrolled units. 
and vary as a function of the models being analyzed (2001-2009; 2009-2013; 2013-2017). That is, the variable assumes the value ' 0 ' for the first year and ' 1 ' for the last year in each period of analysis.

\section{Results}

Figure 1 displays descriptive data of voter turnout levels in SMU elections during the period of 2001-2017. There is a tendency for a decrease in voter turnout in SMU elections, starting in 2005 and reaching a low point in 2013, whether we are considering amalgamated or nonamalgamated SMUs. This is followed by a small recovery in the 2017 election.

[Figure 1 about here]

However, the trend before the territorial reform is not the same as the one recorded after it. One of the main concerns in analyzing the effects of the territorial reform on voter turnout in 2013 and 2017 is to validate the results from the DiD method to ensure that the differences encountered are the result of the treatment and not the consequence of a previous trend. Figure 1 indicates a similar turnout pattern for (soon-to-be) amalgamated and nonamalgamated SMUs in the period before the reform. However, this common pattern changes in the 2013 election, providing visual confirmation of the differences identified in the DiD method. The analysis of the trend allows us to dispel possible endogeneity problems. The trend is very similar for both groups of SMUs before the territorial reform (2001-2009), but substantially divergent after it (2013 and 2017). This dispels the idea that the groups could already record divergent levels of turnout prior to the reform. It also provides more confidence in the argument that the territorial reform has a negative effect on voter turnout levels in amalgamated SMUs. 
Table 4 presents the results of the DiD model. The amalgamation process had a negative effect on the levels of electoral participation in amalgamated SMUs.

[Table 4 about here]

Before the reform, differences in turnout between the treated and untreated groups are not

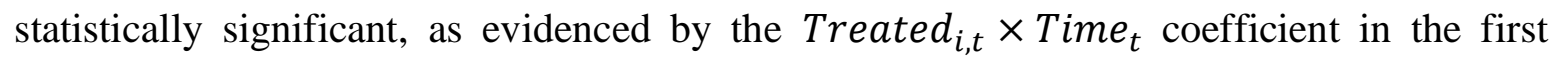
column (Model 1 - 2001-2009). With the treatment - the 2013 territorial reform - the amalgamated SMUs recorded a higher drop in turnout than they would have experienced in the absence of the treatment. The term Treate $_{i, t} \times$ Time $_{t}$ displays a value of -1.242 , which represents the average reduction in turnout that can be accounted for by the effect of the territorial reform. Before the amalgamations, the treated group recorded a level of voter turnout of $64.813 \%$. Following the DiD method rationale, in 2013, an average drop of 3.411 percentage points was expected, simply as a result of the continuing decline in voter turnout. Instead, the amalgamated group registered an extra average drop (1.242 more than the nonamalgamated SMUs, as evidence by the $\beta_{4}$ in model $2-2009-2013$ ). This finding supports the first hypothesis, indicating that the territorial reform resulted in a lower turnout for amalgamated parishes of -4.653 percentage points (=-3.411 - 1.242). In contrast, nonamalgamated SMUs recorded a smoother drop in turnout of 3.41 percentage points $\left(\beta_{3}\right.$ in model $\left.2-2009-2013\right)$. The magnitude of the effect of the Portuguese reform is quite similar to the drop in turnout registered in the Austrian state of Styria as reported by Heinisch et al. (2018) (1.29 percentage points).

Participation grew in the 2017 election, both in amalgamated and non-amalgamated SMUs. This result is in line with our second hypothesis, since it was expected that the effect of the 
protest vote would fade away with time. Still, differences in turnout between the two groups are visually and statistically discernible. Again, due to the territorial reform, the treated group recorded a lower increment in turnout than it would have had if these SMUs had not been subjected to the treatment. The term Treated $_{i, t} \times$ Time $_{t}$ displays a value of -0.903 ( $\beta_{4}$ in model $\left.3-2013-2017\right)$, which represents the average difference in turnout between merged and non-merged SMUs that can be accounted for by the territorial reform. In 2013 , the treated group recorded a level of voter turnout of $60.264 \%$. Following the estimation of the term Time $_{i, t}$, an increment of 1.644 percentage points ( $\beta_{3}$ in model 3 ) was expected for the 2017 election. Instead, the average increment for the merged group was lower by -0.903 percentage points than the average increment in turnout for the control group (1.644). In line with the findings for the 2013 election, the territorial reform caused a smaller increase in turnout in amalgamated SMUs. This finding confirms the second hypothesis, indicating that the recovery in voter turnout levels was less evident in amalgamated SMUs. The average pace of recovery in merged municipalities was 0.741 percentage point $(=1.644$ - 0.903). These findings are consistent with prior results indicating a substantial negative impact on the first election after the reform that tends to be less pronounced after in the second election (Koch and Rochat, 2017).

The results of the variable Treated $_{i, t-1}$ support the argument of the negative impact of the territorial reform on the turnout of SMUs. The coefficient indicates the initial differences in voter turnout between merged and non-merged SMUs. It fails to achieve statistical significance in both models 1 and 2, showing no relevant differences between the two groups before the territorial reform. This result also serves as a robustness check for possible endogeneity, suggesting that there were no differences in turnout between the two groups 
before the reform. In model 3, after the territorial reform, the result already displays a relevant difference among groups.

The results for the control variable have, as expected, a negative impact on the level of voter turnout. The coefficient is negative and statistically significant for all periods, indicating that urban SMUs experience the lower turnout rates, thus confirming prior findings in the Portuguese setting (Tavares and Raudla, 2018).

In sum, the results from the DiD method confirm $\mathrm{H}_{1}$, and $\mathrm{H}_{2}$. The territorial reform reduced turnout levels in amalgamated SMUs compared to non-amalgamated SMUs. In the first election after the reform, merged municipalities experienced a significantly lower turnout than previous elections. In the following election, turnout recovered, but, again, this recovery was more substantial in non-amalgamated SMUs than in amalgamated ones.

\section{Conclusion}

The goal of this research is to cast new light on the political costs of territorial reforms. We investigated this important research question by focusing on the heretofore neglected amalgamation reform of SMUs in Portugal. Our results indicate that the amalgamation process had a negative effect on voter turnout. Hence, a territorial reform motived by economic factors and triggered by a situation of financial distress, resulted in negative democratic outcomes translated into lower electoral participation levels.

In our theoretical section, we posited three causal mechanisms that could potentially explain the negative effect of amalgamations on voter turnout: rational voting, declining social cohesion and trust, and perceived loss of local identity. Our goal was not to identify which of these mechanisms was specifically responsible for the decline in turnout in the case of the 
Portuguese reform, but rather to assess whether this negative effect occurred and, if so, its magnitude. The results confirm our hypotheses regarding the negative effect of amalgamations on turnout and counter the view that increased size through amalgamations might work as a trigger for the mobilization of electoral participation.

Under the lenses of the Downsian model, the amalgamation process is likely to reduce the relevance of the act of voting by diminishing the probability that an individual casts the decisive vote (Downs, 1957). Similarly, the social trust model suggests that the socioeconomic status, particularly social cohesion, is altered through the process of amalgamation, thus hindering political engagement expressed through voter turnout (Swianiewicz, 2002; Denters et al., 2014). The significant reduction of turnout in amalgamated SMUs in the first election after the reform combined with the recovery of turnout in the second election also may support the idea of a short-term abstention as a form of political protest against the reform.

Our results regarding turnout in the 2013 election are consistent with the arguments of the rational voter, the social cohesion, and the political protest explanations, but we are unable to disentangle which theoretical mechanism has the strongest role in causing the observed effects on voter turnout levels. In addition, it is also possible that the financial crisis and the 2011 bailout contributed to the migration of voting age population and to a decline in voter confidence in Portugal, resulting in lower turnout rates in the 2013 election. We have no means to untangle these effects in our analyses, and it is also impossible to show whether this crisis effect had disappeared by 20177. Citizen survey data could have helped to tease out the

7 We are grateful to an anonymous reviewer for pointing out this possibility. 
magnitude of these effects, but to our knowledge no such data was collected for Portugal, so these stimulating research questions will remain unanswered in the foreseeable future.

Furthermore, we argue that the effect of amalgamations on voter turnout is more complex than previously thought. The 2017 turnout levels in amalgamated parishes is higher compared to 2013, but the difference between amalgamated and non-amalgamated SMUs is still increasing. This suggests that amalgamation reforms are 'a gift that keeps on giving', with their negative effects lingering for a long time after they have been institutionalized. This is also consistent with the idea that the incentives to vote may be permanently reduced for residents in amalgamated SMUs.

The results of these analyses suggest two different avenues for future research. The first possibility is to focus only on the amalgamated SMUs and analyze how their heterogeneity before amalgamation has impacted voter turnout. The process of creation of amalgamated SMUs agglomerated SMUs of different sizes and voter turnout levels. A relevant contribution to the field should analyze how the amplitude of sizes and prior levels of turnout has conditioned the levels of turnout in the newly amalgamated SMUs. The second idea to explore in future research is to concentrate on other democratic outcomes. Due to limited data availability, our research was primarily interested in voter turnout as a political participation variable. However, territorial reforms affect democratic performance at many levels, including political efficacy, political representation, and support for the incumbents at the municipal level. These political consequences are relevant topics of research, ripe to be investigated by scholars interested in territorial reforms. 


\section{References}

Allers. M.A.\& Geertsema, J.B. (2016). The effects of local government amalgamation on public spending. taxation. and service levels: Evidence from 15 years of municipal consolidation. Journal of Regional Science, 56(4), 659-682.

Bäck, H., Gjelstrup, G., Helgessen, M., Johansson, F. \& Klausen, J. E. (2005). Urban Political Decentralization: Six Scandinavian Cities. Wiesbaden: Verlag für Sozialwissenschaften.

Bikker. J. \& van der Linde. D. (2016). Scale economies in local public administration. Local Government Studies, 42(3), 441-463.

Blesse. S. \& Baskaran. T (2016). Do municipal mergers reduce costs? Evidence from a German federal state. Regional Science and Urban Economics, 59, 54-74.

Blom-Hansen, J. (2010). Municipal amalgamations and common pool problems: The Danish local government reform in 2007. Scandinavian Political Studies, 33(1), 51-73.

Blom-Hansen, J., Houlberg, K. \& Serritzlew, S. (2014). Size, democracy, and the economic costs of running a political system. American Journal of Political Science, 58(4), 790-803.

Blom-Hansen, J., Houlberg, K., Serritzlew, S. \& Treisman, D. (2016) Jurisdiction size and local government policy expenditure: Assessing the effect of municipal amalgamation. American Political Science Review, 110(4), 812-831.

Boettke, P.J., Coyne, C.J., \& Leeson, P.T. (2008) Institutional Stickiness and the New Development Economics. American Journal of Economics and Sociology, 67(2), 331-358. 
Cancela, J. \& Geys, B. (2016). Explaining voter turnout: A meta-analysis of national and subnational elections. Electoral Studies, 42, 264-275.

Chorianopoulos, I (2011). State spatial restructuring in Greece: Forced rescaling. unresponsive localities. European Urban and Regional Studies, 19(4), 331-348.

CoE (1995). The size of municipalities: Efficiency and citizen participation. Study Series: Local and Regional Authorities in Europe. Report n. ${ }^{\circ}$ 56. Strasbourg: Council of Europe Press.

Dagger, R (1981). Metropolis, memory, and citizenship. American Journal of Political Science, 25(4), 715-737.

Dahl, R.A. (1967). The city in the future democracy. American Political Science Review, 61, 953-970.

Dahl, R.A. \& Tufte, E. (1973). Size and Democracy. Stanford. CA: Stanford University Press.

De Ceuninck, K., Reynaert, H., Steyvers, K. \& Valcke, T. (2010). Municipal amalgamations in the Low Countries: Same problems, different solutions. Local Government Studies, $36(6), 803-822$.

Denters, B., Goldsmith, M., Ladner, A., Mouritzen, P.E. \& Rose, L. (2014). Size and Local Democracy. Cheltenham: Edward Elgar.

Downs. A. (1957). An Economic Theory of Democracy. New York: Harper \& Row. 
Fathimath, A. (2017) Impact of municipal amalgamation on stakeholder collaboration: the case of Auckland. New Zealand. Kõtuitui: New Zealand Journal of Social Sciences Online, 12(2), 221-234.

Frandsen, A.G. (2002). Size and electoral participation in local elections. Environment and Planning C: Government and Policy, 20, 853-869.

Gendźwill, A. \& Swianiewicz, P. (2016). Does local democracy perform better in smaller jurisdictions? Survey evidence from Poland. Lex Localis - Journal of Local SelfGovernment, 14(4), 759-782.

Gertler. P. J., Martinez, S., Premand, P., Rawlings, L.B. \& Vermeersch, C.M.J. (2011) Impact Evaluation in Practice. Washington, DC: The World Bank.

Geys, B. (2006). Explaining voter turnout: A review of aggregate-level research. Electoral Studies, 25, 637-63.

Hajnal. Z.L. \& Lewis, P.G. (2003). Municipal institutions and voter turnout in local elections. Urban Affairs Review, 38(5), 645-668.

Hanna, N. (2009). An argument for voting abstention. Public Affairs Quarterly, 23(4), 275286.

Hansen, S.W. (2013). Polity size and local political trust: A quasi-experiment using municipal mergers in Denmark. Scandinavian Political Studies 36(1), 43-66.

Hansen, S.W. (2014). Common pool size and project size: An empirical test on expenditures using Danish municipal mergers. Public Choice, 159(1-2), 3-21. 
Hansen, S.W. (2015). The democratic costs of size: How increasing size affects citizen satisfaction with local government. Political Studies 63(2), 373-389.

Hansen, S.W., Houlberg, K., \& Pedersen, L.H. (2014). Do municipal mergers improve fiscal outcomes? Scandinavian Political Studies 37(2), 196-214.

Heinisch, R., Lehner, T., Mühlböck, A. \& Schimpf, C.H. (2018). How do municipal amalgamations affect turnout in local elections? Insights from the 2015 municipal reform in the Austrian state of Styria. Local Government Studies, 44(4): 465-491.

Hlepas, N-K. (2018). Between identity politics and the politics of scale: Sub-municipal governance in Greece. In Hlepas. N-K., Kersting, N., Kuhlmann, S., Swianiewicz. P. \& Teles, F. (eds.) Sub-Municipal Governance in Europe: Decentralization beyond the municipal tier. London: Palgrave Macmillan, pp. 119-143.

Horak, M. \& Blokland, T. (2012). Neighborhoods and civic practice. In John, P., Mossberger, K., \& Clarke, S. E. (eds.) The Oxford Handbook of Urban Politics. Oxford University Press.

Horiuchi, Y., Saito, J. \& Yamada, K. (2015). Removing boundaries, losing connections: Electoral consequences of local government reform in Japan. Journal of East Asian Studies, 15, 99-125.

van Houwelingen, P. (2017). Political participation and municipal population size: A metastudy. Local Government Studies, 43(3), 408-428.

Imran, M. \& Pearce, J. (2015). Auckland's first spatial plan: Ambitious aspirations or furthering the status quo? Cities, 45, 18-28. 
Jakobsen. M., \& Kjaer, U. (2016). Political representation and geographical bias in amalgamated local governments. Local Government Studies, 42(2), 208-227.

Kellerher, C. \& Lowery, D. (2004). Political participation and metropolitan institutional contexts. Urban Affairs Review, 39(6): 720-757.

Kjaer, U., Hjelmar, U., \& Olsen, A.L. (2010). Municipal amalgamations and the democratic functioning of local councils: The case of the Danish 2007 structural reform. Local Government Studies, 36(4), 569-585.

Kjaer, U. \& Klemmensen, R (2015). What are the local political costs of centrally determined reforms of local government. Local Government Studies, 41(1), 100-118.

Koch, P. \& Rochat, P. E. (2017). The effects of local government consolidation on turnout: Evidence from a quasi-experiment in Switzerland. Swiss Political Science Review, 23(3): $215-230$.

Kraaykamp, G., van Dam, M., \& Toonen, T. (2001). Institutional change and political participation: The effects of municipal amalgamation on electoral turnout in the Netherlands. Acta Politica, 36(4), 402-418.

Ladner. A. (2002). Size and direct democracy at the local level: The case of Switzerland. Environment and Planning C: Government and Policy, 20(6), 813-828.

Lapointe, S., Saarimaa, T. \& Tukiainen, J. (2018). Effects of municipal mergers on voter turnout. Local Government Studies, 44(4), 512-530.

Larsen, C.A. (2002). Municipal size and democracy: A critical analysis of the argument of proximity based in the case of Denmark. Scandinavian Political Studies, 25(4), 317-332. 
Lassen. D. \& Serritzlew. S. (2011). Jurisdiction size and local democracy: Evidence on internal political efficacy from large-scale municipal reform. American Political Science Review, 105(2), 238-258.

Mabuchi, M. (2001). Municipal amalgamation in Japan. Washington, DC: World Bank.

McArthur, J. (2017). Auckland: Rescaled governance and post-suburban politics. Cities, 64, 79-87.

McDonnell, J. (2019). Municipal size, political efficacy and political participation: a systematic review. Local Government Studies. https://doi.org/10.1080/03003930.2019.1600510 .

Newton. K. (1982). Is small really so beautiful? Is big really so ugly? Size. effectiveness. and democracy in local government. Political Studies, 30(2), 190-206.

Oliver, J.E. (2001). Democracy in Suburbia. Princeton. NJ: Princeton University Press.

Oliver, J.E. (2012) Local Elections and the Politics of Small-Scale Democracy. Princeton. NJ: Princeton University Press.

Peteri, G. (2008). Mind your own Business: Community Governance in Rural Municipalities. Budapest: LGI/Open Society Institute.

Pierson, P. (2000a) The Limits of Design: Explaining Institutional Origins and Change. Governance, 13(4), 475-499.

Pierson, P. (2000b). Returns, Path Dependence and the Study of Politics. American Political Science Review, 94(2), 251-267. 
Poel, D.H. (2000) Amalgamation perspectives: Citizen responses to municipal consolidation. Canadian Journal of Regional Science, 23(1), 31-48.

PORDATA (2019) Base de Dados Portugal Contemporâneo. Assessed on October 22, 2019. https://www.pordata.pt/DB/Municipios/Ambiente+de+Consulta/Tabela

Riker, W.H. \& Ordeshook, P.C. (1968). A theory of the calculus of voting. American Political Science Review, 62(1), 25-42.

Roesel, F. (2017). Do mergers of large local governments reduce expenditures? Evidence from Germany using the synthetic control method. European Journal of Political Economy, 50, 22-36.

Saarimaa, T. \& Tukiainen, J. (2015). Common pool problems in voluntary municipal mergers. European Journal of Political Economy, 38, 140-152.

Schaap, L. \& Daemen, H. (Eds.) (2012). Renewal in European Local Democracies. Wiesbaden: Springer.

Simmel, G. (1903). The metropolis and mental life. In Bridge, G. \& Watson, S. (eds.). 2010. The Blackwell City Reader. Oxford: Wiley-Blackwell.

Steiner, R. \& Kaiser, C. (2017). Effects of amalgamations: Evidence from Swiss municipalities. Public Management Review, 19(2), 232-252.

Steiner. R., Kaiser. C., \& Eythórsson, G.T. (2017). A comparative analysis of amalgamation reforms in selected European countries. In: Bouckaert, G. \& Kuhlmann, S. (eds.) Local Public Sector Reforms in Times of Crisis: National Trajectories and International Comparisons. London: Palgrave Macmillan: pp.23-42. 
Stoker, G. (2011). Was local governance such a good idea? A global comparative perspective. Public Administration, 89(1), 15-31.

Suzuki. K., \& Sakuwa, K. (2016). Impact of municipal mergers on local population growth: An assessment of the merger of Japanese municipalities. Asia Pacific Journal of Public Administration, 38(4), 223-238.

Swianiewicz, P. (2002) Size of local government. local democracy and efficiency in delivery of local services-International context and theoretical framework. In: Swianiewicz, P. (ed.). Consolidation or Fragmentation? The Size of Local Governments in Central and Eastern Europe. Budapest: LGI/Open Society Institute. pp.1-29.

Swianiewicz, P. (2010). If territorial fragmentation is a problem. is amalgamation a solution? An East European perspective. Local Government Studies, 36(2), 183-203.

Swianiewicz, P. (2015) Intra-municipal units in urban political systems in Poland: Vicious roundabout of marginalization or dead-end street? The NISPACEE Journal of Public Administration and Policy, 7 (2): 173-198.

Swianiewicz, P. (2018) If territorial fragmentation is a problem. is amalgamation a solution? - Ten years later. Local Government Studies, 44(1), 1-10.

Tavares, A.F. (2015). Reformas territoriais: Fusões de municípios e cooperação intermunicipal. In: de Sousa. L., Tavares. A., Cruz. N.F. \& Jorge, S. (eds.). A reforma do poder local em debate. Lisboa: ICS.

Tavares, A.F. (2018). Municipal amalgamations and their effects: A literature review. Miscellanea Geographica - Regional Studies on Development, 22(1), 5-15. 
Tavares, A.F. \& Carr. J.B. (2013). So close, yet so far away? The effects of city size, density, and growth on local civic participation. Journal of Urban Affairs, 35(3), 283-302.

Tavares, A.F. \& Raudla, R. (2018). Size, density and small scale elections: A multi-level analysis of voter turnout in sub-municipal governments. Electoral Studies, 56 (December), 1-13.

Tavares. A.F. \& Rodrigues, M. (2015) The economic and political impacts of top-down territorial reforms: The case of Portuguese parishes. Local Government Studies, 41(6), 956-976.

Tavares, A.F. \& Teles, F. (2018). Deeply rooted but still striving for a role: The Portuguese freguesias under reform. In: Hlepas, N-K., Kersting, N., Kuhlmann, S., Swianiewicz, P. \& Teles, F. (eds) Sub-Municipal Governance in Europe: Decentralization beyond the Municipal Tier. London: Palgrave Macmillan, pp. 193-209.

Teles, F. (2016). Local government and the bailout: Reform singularities in Portugal. European Urban and Regional Studies, 23(3), 455-467.

Trounstine, J. (2013). Turnout and incumbency in local elections. Urban Affairs Review, 49(2), 167-189.

Verba. S., Nie, N.H. \& Kim, J. (1978). Participation and Political Equality: A Seven-Nation Comparison. Chicago, IL: University of Chicago Press.

Vojnovic, I. (2000). The transitional impacts of municipal consolidations. Journal of Urban Affairs, 22(4), 385-411.

Wood, C. (2002) Voter turnout in city elections. Urban Affairs Review, 38(2), 209-231. 
Zeedan, R. (2017). Bigger but not always better: Size and democracy in Israeli amalgamated local governments. Journal of Urban Affairs, 39(5), 711-728.

Figure 1 - Turnout in SMU elections (2001-2017)

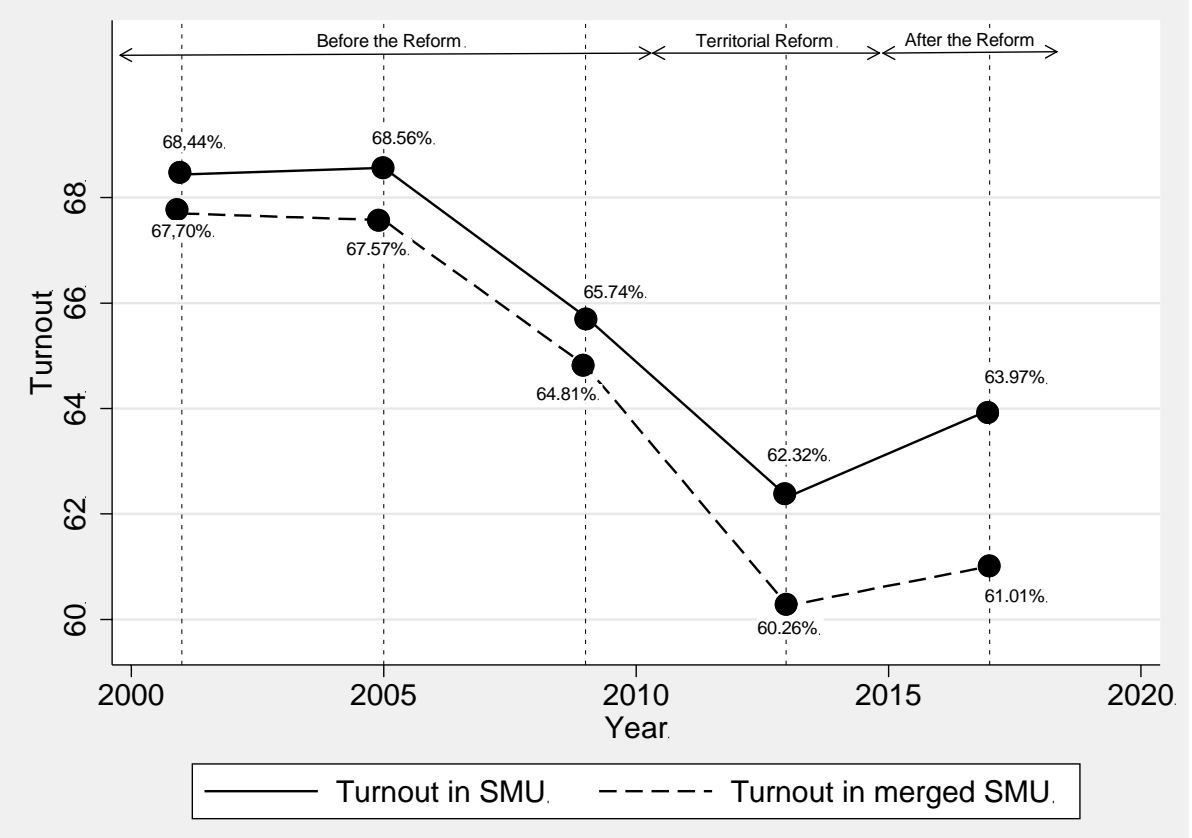


Table 1 - The Political Effects of Municipal Amalgamations

\begin{tabular}{|c|c|c|c|c|c|c|}
\hline Author(s) & Date & Journal & Country & Data & Methods & Findings \\
\hline $\begin{array}{l}\text { Elklit and } \\
\text { Kjaer }\end{array}$ & 2009 & SPS & Denmark & $\begin{array}{l}\text { Combination of } \\
\text { general electoral } \\
\text { statistics with large } \\
\text { voter surveys and } \\
\text { quasi-experimental } \\
\text { setting offered by the } \\
\text { fact that not all } \\
\text { municipalities were } \\
\text { amalgamated. }\end{array}$ & $\begin{array}{l}\text { The proportion } \\
\text { of the voters } \\
\text { voting for } \\
\text { different parties } \\
\text { (inter-level split } \\
\text { voting) at the } \\
\text { National and } \\
\text { Municipal Level } \\
\text { in the Elections } \\
\text { of } 2001 \text { and } \\
\text { 2005, Logistic } \\
\text { Regression } \\
\text { Analysis. }\end{array}$ & $\begin{array}{l}\text { Inter-level split-ticket voting between } \\
\text { three levels (national, regional and } \\
\text { local) decreased slightly from } 2001 \text { to } \\
2005 \text { - that is, simultaneously with the } \\
\text { implementation of a major reform, } \\
\text { where many municipalities and all the } \\
\text { counties were amalgamated. These } \\
\text { amalgamations affect the level of split } \\
\text { voting through a process where the } \\
\text { local party system operates as an } \\
\text { intervening variable: the larger } \\
\text { municipalities have a more } \\
\text { nationalized local party system, which } \\
\text { leads to fewer voters being vote } \\
\text { splitters by necessity. }\end{array}$ \\
\hline $\begin{array}{l}\text { Heinisch, } \\
\text { Lehner, } \\
\text { Mühlböck and } \\
\text { Schimpf } \\
\end{array}$ & 2018 & LGS & $\begin{array}{l}\text { Austria } \\
\text { (Styria) }\end{array}$ & $\begin{array}{l}542 \text { municipalities } \\
\text { merged into } 287 \\
\quad(2015)\end{array}$ & OLS regression & $\begin{array}{c}\text { Electoral turnout in merged } \\
\text { municipalities decreased } 1.29 \\
\text { percentage points more than non- } \\
\text { merged municipalities. }\end{array}$ \\
\hline $\begin{array}{l}\text { Horiuchi, Saito } \\
\text { and Yamada }\end{array}$ & 2015 & JEAS & Japan & $\begin{array}{l}1,826 \text { municipalities, } \\
557 \text { of which were } \\
\text { merger. Vote share } \\
\text { of governing parties } \\
\text { and voter turnout in } \\
\text { upper house election. }\end{array}$ & $\begin{array}{l}\text { Difference-in- } \\
\text { differences }\end{array}$ & $\begin{array}{l}\text { Merged municipalities display } \\
\text { significantly lower voter turnout }\end{array}$ \\
\hline $\begin{array}{l}\text { Jakobsen and } \\
\text { Kjaer }\end{array}$ & 2016 & LGS & Denmark & $\begin{array}{c}66 \text { amalgamated } \\
\text { municipalities with } \\
\text { different center- } \\
\text { periphery } \\
\text { dimensions, } 223 \\
\text { former } \\
\text { nonamalgamated } \\
\text { municipalities. }\end{array}$ & $\begin{array}{l}\text { Fixed effects } \\
\text { models; } \\
\text { periphery } \\
\text { representation } \\
\quad \text { index }\end{array}$ & $\begin{array}{l}\text { Over-representation of the periphery in } \\
\text { the legislature of amalgamated } \\
\text { municipalities, both in terms of } \\
\text { representation by seats (descriptive } \\
\text { representation) and representation of } \\
\text { geographical interests (substantive } \\
\text { representation). }\end{array}$ \\
\hline $\begin{array}{c}\text { Kjaer and } \\
\text { Klemmensen }\end{array}$ & 2015 & LGS & Denmark & $\begin{array}{c}98 \text { amalgamated } \\
\text { municipalities, } 3,336 \\
\text { survey respondents }\end{array}$ & $\begin{array}{l}\text { Ordinary least } \\
\text { squares and } \\
\text { multilevel logit } \\
\text { regressions }\end{array}$ & $\begin{array}{l}\text { Local parties of mayors were punished } \\
\text { at the polls for implementing } \\
\text { municipal amalgamations decided by } \\
\text { the central government. Political } \\
\text { parties holding the mayoralty in times } \\
\text { of amalgamations tend to nominate } \\
\text { very tenured mayors as candidates, } \\
\text { thereby missing the positive first-term } \\
\text { incumbency effect, which a new } \\
\text { mayor could have acquired. Voters } \\
\text { tend to reward primarily the success in } \\
\text { providing high quality local services, } \\
\text { not punish the costs of centrally- } \\
\text { mandated amalgamation reforms. }\end{array}$ \\
\hline Kjaer et al. & 2010 & LGS & Denmark & $\begin{array}{l}\text { Two large surveys: } \\
\text { pre-reform survey } \\
\quad(2003,844 \\
\text { respondents, } 61 \% \text { of } \\
\text { all councilors in } 80 \\
\text { municipalities) and } \\
\end{array}$ & $\begin{array}{c}\text { OLS; } \\
\text { Difference-in- } \\
\text { difference } \\
\text { regression } \\
\text { analysis. }\end{array}$ & $\begin{array}{l}\text { Amalgamations have led to an increase } \\
\text { in the perceived influence of leading } \\
\text { councilors vis-à-vis other councilors } \\
\text { and a decrease in the perceived } \\
\text { influence of the council vis-a }{ }^{-} \text {-vis its } \\
\text { top administrative officers. There is an }\end{array}$ \\
\hline
\end{tabular}




\begin{tabular}{|c|c|c|c|c|c|c|}
\hline & & & & $\begin{array}{l}\text { post-reform survey } \\
\quad(2009,1,337 \\
\text { respondents, } 53 \% \text { of } \\
\text { total councilors })\end{array}$ & & $\begin{array}{l}\text { increase in the number of councilors } \\
\text { who find that local political decisions } \\
\text { are determined by laws and rules from } \\
\text { central government, but this increase } \\
\text { cannot be ascribed to the } \\
\text { amalgamations. }\end{array}$ \\
\hline $\begin{array}{c}\text { Koch and } \\
\text { Rochat }\end{array}$ & 2017 & SPSR & $\begin{array}{l}\text { Switzerland } \\
\text { (Canton of } \\
\text { Ticino) }\end{array}$ & $\begin{array}{c}245 \text { pre-merger } \\
\text { municipalities (1996) } \\
\text { and } 147 \text { post-merger } \\
\text { municipalities (2012) } \\
\text { in three merger } \\
\text { 'waves' }\end{array}$ & $\begin{array}{l}\text { OLS panel fixed } \\
\text { effects } \\
\text { regression }\end{array}$ & $\begin{array}{c}\text { Turnout decreases more significantly } \\
\text { in merged municipalities, particularly } \\
\text { in the first election after the first } \\
\text { merger 'wave'. }\end{array}$ \\
\hline $\begin{array}{l}\text { Lapointe, } \\
\text { Saarimaa and } \\
\text { Tukiainen }\end{array}$ & 2018 & LGS & Finland & $\begin{array}{l}61 \text { municipalities. } \\
\text { Two pre-merger and } \\
\text { three post-merger } \\
\text { elections }\end{array}$ & $\begin{array}{l}\text { Nonparametric } \\
\text { nearest- } \\
\text { neighbour } \\
\text { matching } \\
\text { algorythm and } \\
\text { Difference-in- } \\
\text { differences }\end{array}$ & $\begin{array}{c}\text { Municipal mergers decrease voter } \\
\text { turnout by } 4 \text { percentage points in small } \\
\text { municipalities compared to similar } \\
\text { municipalities that did not merge. No } \\
\text { effect for larger municipalities that } \\
\text { merged. }\end{array}$ \\
\hline $\begin{array}{l}\text { Lassen and } \\
\text { Serritzlew }\end{array}$ & 2011 & APSR & Denmark & $\begin{array}{l}\text { Survey data collected } \\
\text { before ( } 963 \\
\text { respondents) and } \\
\text { after the reform } \\
(1,065 \text { respondents) }\end{array}$ & $\begin{array}{l}\text { Difference-in- } \\
\text { difference and } \\
\text { matching } \\
\text { estimators }\end{array}$ & $\begin{array}{c}\text { Jurisdiction size has a causal and } \\
\text { sizeable detrimental effect on citizens' } \\
\text { internal political efficacy }\end{array}$ \\
\hline Mabuchi & 2001 & $\begin{array}{l}\text { World } \\
\text { Bank }\end{array}$ & Japan & 4 Prefectures & $\begin{array}{l}\text { Comparative } \\
\text { analysis of } \\
\text { descriptive } \\
\text { election data }\end{array}$ & $\begin{array}{l}\text { Voter turnout is not significantly } \\
\text { affected by amalgamations. }\end{array}$ \\
\hline Roesel & 2017 & EJPE & $\begin{array}{l}\text { Germany } \\
\text { (Saxony) }\end{array}$ & $\begin{array}{l}22 \text { county-sized local } \\
\text { governments merged } \\
\text { into } 10, \text { panel data } \\
(1998-2013), \text { district } \\
\text { expenditures }\end{array}$ & $\begin{array}{l}\text { Synthetic control } \\
\text { method }\end{array}$ & $\begin{array}{c}\text { Evidence that mergers decreased the } \\
\text { number of candidates and voter turnout } \\
\text { in district elections while vote shares } \\
\text { for populist right-wing parties } \\
\text { increased. }\end{array}$ \\
\hline Zeedan & 2017 & JUA & Israel & $\begin{array}{c}24 \text { amalgamated } \\
\text { governments, panel } \\
\text { data for voter turnout } \\
\quad(1998-2013)\end{array}$ & $\begin{array}{l}\text { OLS, Between } \\
\text { effects } \\
\text { regression } \\
\text { analysis }\end{array}$ & $\begin{array}{c}\text { Amalgamation reduces local } \\
\text { democracy in terms of voter turnout } \\
\text { and representation. A new } \\
\text { amalgamated government must be } \\
\text { sufficiently small to maximize local } \\
\text { democracy and sufficiently large to } \\
\text { maximize economies of scale. }\end{array}$ \\
\hline
\end{tabular}

Notes: APSR = American Political Science Review; EJPE = European Journal of Political Economy; JEAS = Journal of East Asian Studies; JUA = Journal of Urban Affairs; LGS = Local Government Studies; SPSR = Swiss Political Science Review; SPS = Scandinavian Political Studies. 
Table 2 - Sub-Municipal Units per number of registered voters

\begin{tabular}{|c|c|c|c|c|}
\hline SMU registered voters & \multicolumn{2}{|c|}{$\begin{array}{c}\text { Before the reform } \\
\text { (2013) }\end{array}$} & \multicolumn{2}{c|}{ After the reform (2013) } \\
\hline & SMUs & \% & SMUs & 0.23 \\
\hline Less than 150 & 177 & 4.16 & 7 & 45.44 \\
\hline Between 150 and 1,000 & 1,989 & 46.79 & 1405 & 41.66 \\
\hline Between 1,000 and 5,000 & 1,637 & 38.51 & 1288 & 9.67 \\
\hline Between 5,000 and 20,000 & 375 & 8.82 & 299 & 3.01 \\
\hline More than 20,000 & 73 & 1.72 & 93 & $\mathbf{1 0 0}$ \\
\hline Total number of SMUs & $\mathbf{4 , 2 5 1}$ & $\mathbf{1 0 0}$ & $\mathbf{3 0 9 2}$ & \\
\hline
\end{tabular}

Note: An average of 2,483 inhabitants per parish before the reform and an average of 3,414 inhabitants after the 2013 Reform. The average number of inhabitants in the 308 Portuguese municipalities is 34,273.

Source: DGAL - Direcção Geral das Autarquias Locais $(2003,2014)$

Table 3 - Sub-Municipal Units per area in square kilometers

\begin{tabular}{|c|c|c|c|c|}
\hline SMU area & \multicolumn{2}{|c|}{$\begin{array}{c}\text { Before the reform } \\
\text { (2013) }\end{array}$} & \multicolumn{2}{c|}{ After the reform } \\
\hline Less than 1 sq. km & Parishes & $\%$ & Parishes & $\%$ \\
\hline Between 1 and 5 sq. kms & 70 & 1.65 & 2 & 0.06 \\
\hline Between 5 and 10 sq. kms & 943 & 22.18 & 378 & 12.23 \\
\hline Between 10 and 50 sq. kms & 931 & 21.90 & 581 & 18.79 \\
\hline Between 50 and 100 sq. kms & 1928 & 45.35 & 1719 & 55.60 \\
\hline Between 100 and 200 sq. kms & 226 & 5.32 & 248 & 8.02 \\
\hline Between 200 and 400 sq. kms & 123 & 2.89 & 118 & 3.82 \\
\hline More than 400 sq. kms & 29 & 0.68 & 42 & 1.36 \\
\hline Total number of SMUs & 1 & 0.02 & 4 & 0.13 \\
\hline
\end{tabular}

Note: On average, each parish had 21.66 square kms. before 2013 and 29.78 square kms. after the 2013 Reform

Source: DGAL - Direç̧ão Geral das Autarquias Locais $(2003,2014)$ 
Table 4 - Estimation Results of Difference-in-Differences

\begin{tabular}{l|ccc}
\hline & Model 1 & Model 2 & Model 3 \\
\hline & $2001-2009$ & $2009-2013$ & $2013-2017$ \\
\hline Treated $_{i, t-1}$ & -0.109 & -0.144 & $-1.271 * * *$ \\
(Initial difference among groups) & $(0.356)$ & $(0.378)$ & $(0.353)$ \\
Time $_{i, t}$ & $-2.697 * * *$ & $-3.411^{* * *}$ & $1.646^{* * * *}$ \\
(Changes not accounted for by the treatment) & $(0.281)$ & $(0.291)$ & $(0.239)$ \\
Treated $_{i, t} \times$ Time $_{t}$ & -0.184 & $-1.242^{* *}$ & $-0.903 *$ \\
(Average effect of the treatment on treated) & $(0.501)$ & $(0.505)$ & $(0.497)$ \\
Type $_{i, t}$ & $-4.458 * * *$ & $-5.505 * * *$ & $-6.446 * * *$ \\
(Control for the urban vs. non-urban SMUs) $^{2}$ & $(0.277)$ & $(0.283)$ & $(0.282)$ \\
\hline$R^{2}$ & 0.06 & 0.10 & 0.09 \\
RMSE & 8.01 & 9.121 & 9.203 \\
$N$ & 5,734 & 5,892 & 6,040 \\
\hline
\end{tabular}

$p<0.1 ; * * p<0.05 ; * * * p<0.01$ 
Appendix - Portuguese Sub-Municipal Units in Comparative Perspective

\begin{tabular}{|c|c|c|c|c|c|c|c|c|}
\hline Country & $\begin{array}{c}\text { Before } \\
\text { Reform } \\
\# 2013\end{array}$ & $\begin{array}{c}\text { After } \\
\text { Reform } \\
\# 2013\end{array}$ & $\Delta \#$ & $\Delta \%$ & $\begin{array}{c}\text { Mean } \\
\text { Area 2012 } \\
(\mathbf{k m 2})\end{array}$ & $\begin{array}{c}\text { Mean } \\
\text { Area 2013 } \\
(\mathbf{k m 2})\end{array}$ & $\begin{array}{c}\text { Mean } \\
\text { Population } \\
(2012)\end{array}$ & $\begin{array}{c}\text { Mean } \\
\text { Population } \\
(\mathbf{2 0 1 3 )}\end{array}$ \\
\hline $\begin{array}{l}\text { Portugal } \\
(\text { SMUs })\end{array}$ & 4251 & 3092 & -1177 & -27.57 & 21.73 & 29.94 & 2470 & 3416 \\
\hline Municipalities & \#1950 & \#2007 & $\Delta \#$ & $\Delta \%$ & $\begin{array}{c}\text { Mean } \\
\text { Area }(\mathbf{1 9 5 0 )}\end{array}$ & $\begin{array}{c}\text { Mean } \\
\text { Area (2007) } \\
\end{array}$ & $\begin{array}{c}\text { Mean } \\
\text { Pop. }(1950) \\
\end{array}$ & $\begin{array}{c}\text { Mean } \\
\text { Pop. }(2007) \\
\end{array}$ \\
\hline Austria & 3999 & 2358 & -1641 & -41.04 & 20.97 & 35.56 & 3560 & 3552 \\
\hline France & 38814 & 36783 & -2031 & -5.23 & 14.21 & 15.00 & 1636 & 1707 \\
\hline Czech Rep. & 11459 & 6244 & -5215 & -45.51 & 6.88 & 12.63 & 1641 & 1683 \\
\hline Hungary & 3032 & 3152 & +120 & +3.96 & 30.68 & 29.51 & 3153 & 3177 \\
\hline Portugal & 303 & 308 & +5 & +0.02 & 303.87 & 298.94 & 35491 & 34538 \\
\hline
\end{tabular}

Note: Table includes the number of municipalities in selected countries in 1950 and 2007. Austria and the Czech Republic were included due to the large-scale amalgamation reforms during the 20th century; Austria, Hungary and the Czech Republic were included due to their similarities with Portugal, both in total area and population. All countries have highly fragmented local government systems, even though in the case of Portugal this level of fragmentation is manifested at the sub-municipal level. 